\title{
Porovnání intenzity zatížení při hraní počítačové hry PlayDance na tanečních podložkách a bez nich
}

\section{Comparison of the exercise intensity during playing a computer game PlayDance on dancing pads and without them}

\author{
Pavel Mráz, Dita Lüftnerová, Kateřina Součková, Michal Jahn, Kateřina Levová \\ Fakulta tělesné kultury Univerzity Palackého v Olomouci
}

\begin{abstract}
Abstrakt:
V rámci výzkumu sledujeme míru intenzity zátěže pohybové aktivity při hraní skupinové počitačové hry PlayDance. Srovnáváme hraní na tanečních podložkách s hraním hry na křižích vyznačených na podlaze. Pozorovanou skupinou jsou studenti vysoké školy ve věku 21-26 let, kteři s touto hrou mají minimální zkušenosti, tedy začátečníci. Výzkum porovnává rozdíly v dosažené TF při hře na podložkách a na křrižich u 3 začátečnických obtižností. Porovnání intenzity zátěže na podložkách s intenzitou dosaženou na křižich potvrzuje predpoklad, že míra intenzity zátěže na kř̌žich je nižši než na podložkách. Porovnáni obtižností vzájemně potvrzuje, že intenzita zátěže s obtižností roste. Výjimkou je přechod z obtížnosti 2 na obtižnost 3 u křižũu, kde nebyl nárůst statisticky potvrzen. V dotazníkovém šetřeni se většina hráčù shodla, že vnímají jako zábavnějši a více motivujicí cvičení na podložce. Tato skutečnost nás přivedla k závěru, že nelze doporučit hru na kř́žich vyznačených na podlaze jako samostatnou pohybovou aktivitu, nebot' se zdá, že zde chybí motivace $k$ udržení intenzity zátěže. Doporučujeme hraní provádět na podložkách nebo kombinovat podložky a kř́že.
\end{abstract}

\begin{abstract}
:
The objective of paper is to compare the exercise intensity during playing the active video game PlayDance on dancing pads with playing on crosses marked on the ground. All respondents were student of university, 21-26 years old, with minimum previous experiences with dancing pads. Our research was aimed on comparison the differences in HR between exercise on dancing pads and crosses marked on the ground with regard to 3 basic levels of difficulty. We also were comparing the levels of difficulty between themselves. The research confirmed expectation that the level of exercise intensity is lower on crosses against on dancing pads and also that the exercise intensity increases with the level of difficultness except shifting between level 2 and 3 on crosses. Majority of players answered in the questionnaire that they found playing the game on dancing pads more enjoyable and motivational than on crosses. Therefore, we cannot recommend playing PlayDance on crosses marked on the ground as separated activity without combination with the dancing pads, while it seems that there is lost the motivation for keeping the exercise intensity. We recommend playing PlayDance on dancing pads or using a combination of pads and crosses.
\end{abstract}

Kličová slova: taneční podložky, pohybová aktivita, aktivní počitačová hra, AVG, intenzita zátěže, PlayDance

Keywords: dancing pads, physical activity, active video game, AVG, exercise intensity, PlayDance

\section{ÚVOD}

Změny, které provázejí průmyslový i společenský pokrok a usnadňují tak lidstvu běžné denní činnosti, s sebou přinášejí problematiku nedostatečné úrovně pohybové aktivity obyvatelstva. Jejím přímým důsledkem je rostoucí míra nadváhy a obezity populace spolu s rostoucím výskytem neinfekčních civilizačních onemocnění (Kalman, Hamř́k \& Pavelka, 2009). Ačkoliv existuje řada globálních strategií, které doporučují pravidelnou pohybovou aktivitu, je motivování lidí k navýšení pohybové aktivity a dosažení pozitivního zdravotního efektu velmi komplikované (Stejskal, 2004). Jednou z moderních technologií, které by mohly překonávat tyto bariéry, jsou pohybové počítačové/video hry (zkr. AVG). AVG jsou totiž hodnoceny jako technologie s potenciálem překonávajícím běžné bariéry pro zvýšení míry pohybové aktivity populace (Dunning, 2008; Barnett, 
Cerin \& Baranowski, 2011).

Vzhledem k faktu, že popularita počítačových/video her mezi pubescenty a adolescenty stoupá (Sigmundová, Ansari, Sigmund \& Frömel, 2011; Kalman, Sigmund, Sigmundová, Hamř́ik, Beneš, Benešová \& Csémy, 2011), domníváme se, že lze využít potenciál AVG ve skupinovém cvičení, které umožňuje software PlayDance (až 64 hráčů zapojených pomocí tanečních podložek do hry společně). Jedná se o akční taneční videohru, kterou hráč ovládá pohybem nohou na taneční podložce. Taneční podložku představuje čtverec o rozměrech asi metr krát metr. Ten je rozdělen na jednotlivá pole s šipkami. Šipky fungují jako tlačítka. Úkolem hráče je v rytmu hudby šlapat na šipky v pořadí, které mu určuje program.

S ohledem na finanční náklady spojené s pořízením většího počtu tanečních podložek (např. pro účely školní tělesné výchovy), jsme se zabývali ekonomicky přijatelnější variantou. Na místo skutečných tanečních podložek jsme vyznačili lepicí páskou taneční kř́žž na podlahu tělocvičny. Jedná se o alternativu, kterou doporučuje Mohsen (2005). Cvičení na takto vyznačených křížích, na rozdíl od cvičení na tanečních podložkách, však neposkytuje hráči žádnou zpětnou vazbu o jeho úspěšnosti ve hře, zatímco hra PlayDance zaznamenává chybné došlapy na značky.

Ve výzkumu jsme se tedy zaměřili na sledování rozdílů mezi hraním na křížích a na podložkách a mezi začátečnickými obtížnostmi navzájem. Ověřovali jsme, zda existuje pozorovatelný rozdíl mezi intenzitou pohybu prováděného na podložce a intenzitou pohybu prováděného na kř́ži při zachování stejné herní obtížnosti. Porovnávali jsme i náročnost jednotlivých začátečnických úrovní obtížnosti (tedy obtížnosti 1-3), abychom zjistili, která z obtížností se pohybuje v jakém rozmezí intenzity zátěže a zda je mezi nimi rozdíl.

\section{METODIKA}

Zkoumanou skupinou byli studenti vysoké školy. Věk se pohyboval v rozmezí $21-26$ let. Výzkumu se zúčastnilo celkem 15 hráčů, 9 žen a 6 mužů. Do výzkumu byly zařazeny pouze osoby, které měly minimální (1-2krát), respektive žádnou zkušenost $s$ taneční podložkou. $Z$ výzkumu byla tedy vyřazena žena, která použivá podložky na firemních akcích a další 4 osoby (1 muž, 3 ženy) kvůli nekvalitnímu záznamu při monitorování jejich srdeční frekvence. Všichni hráči vyplňovali anonymně dotazník. Zjišt’ovali jsme pohlaví, věk, zkušenosti s tanečními podložkami. K přiřazení dotazníků ke kompatibilnímu záznamu ze sporttesteru jsme použili číselné označení monitorů srdeční frekvence.

Před vlastním měřením byli hráči seznámeni s tanečními podložkami a proběhl praktický nácvik, který trval 11 minut (5 minut první skupina na podložkách a 5 minut druhá, 1 minutu trvalo střídání). Pro rozcvičení byl zvolen první stupeň obtížnosti. Následovalo předání monitorů srdeční frekvence s instrukcí, jak s nimi zacházet.

Pro měření byly použity monitory srdeční frekvence Polar RS 400. K výzkumu jsme se rozhodli použít software PlayDance (freeware verze pro 8 osob) a taneční podložky X-PAD od firmy Konani, nebot' se jedná o jednu z nejprodávanějších variant AVG v současnosti (Biddiss \& Irwin, 2010), která nám navíc umožnila simulovat skupinová cvičení.

Měření bylo rozděleno do dvou shodných bloků. Testované osoby byly rozděleny na dvě skupiny na základě náhodného výběru, přičemž jedna absolvovala první blok měření na podložkách (byla označena červeným pruhem na monitorech srdeční frekvence) a druhý blok na křížích. Druhá skupina byla měřena nejprve na křížích a poté na podložkách (žlutý pruh na monitorech srdeční frekvence). Tento postup byl zvolen proto, aby bylo možné vyloučit vliv zkušenosti nabyté při prvním bloku měření na míru intenzity zátěže při cvičení druhém.

Celé měření trvalo 1 hodinu 23 minut. Oba bloky byly složeny ze tří částí. Každá část měla odlišnou obtížnost. Pro toto měření jsme zvolili obtížnost jedna až tři v kategorii začátečník. První a třetí část trvala 11 minut, druhá pak 10 minut 20 vteřin. Naší snahou bylo zachovat interval kontinuální pohybové aktivity alespoň 10min (WHO, 2010) pro její pozitivní zdravotní efekt. Po jednotlivých částech následovala vždy dvouminutová přestávka na zklidnění organismu. 2minutová přestávka byla zvolena z důvodu časové náročnosti celého výzkumu, který se musel vtěsnat do $90 \mathrm{~min}$. Pokles TF byl na místě ověřován pouze slovním dotazem, nebylo cílem dosažení absolutního TF klid, nebot' byla sledována průměrná TF při dané pohybové aktivitě, tudíž bylo naopak žádoucí dosažení rovnovážného stavu TF. Mezi bloky si hráči mohli doplnit tekutiny, zklidnit organismus a vyměnili si pozice. Přestávka trvala 5 minut, nebot' byl tentokrát žádoucí větší pokles TF. Oba bloky byly sestaveny ze shodných skladeb, bylo zachováno i jejich pořadí, proto je považujeme za porovnatelné. Po ukončení měření jsme anonymně zjišt'ovali, zda hráče více motivoval pohyb na podložce, nebo naopak na křížích vyznačených na podlaze.

Ke zpracování výsledků výzkumu jsme využili průměr TF naměřených při jednotlivých obtížnostech, přičemž 
jsme sledovali rozdíly u téže osoby při cvičení na podložkách a na kř́žžích, a to u obou skupin stejně. Pro zjištění, zda je pohybová aktivita na podložkách i na kř́žžích stejně intenzivní či rozdílná, jsme použili parametrického párového T- testu, který slouží k testování rozdílů mezi závislými výběry (Gajda \& Zvolská, 1982). Tento test jsme zvolili proto, nebot' sleduje rozdíl středních hodnot pro hodnoty získané na podložkách a na kř́žích. Na základě získaných výsledků jsme pak mohli rozhodnout o statistické významnosti při odlišení PA na křížích a na podložkách. Hladinu významnosti jsme zvolili $\alpha=0,05$ na základě běžně používané a uznávané hodnoty.

K porovnání míry intenzity zatížení na podložkách i křížích jsme taktéž využili párového T-testu i stejné hladiny významnosti. Sledovali jsme vzájemnou korelaci mezi jednotlivými obtížnostmi, zvlášt’ u podložek a zvlášst' u kř́žůu.

Závěrem jsme zkonfrontovali výsledky své analýzy s odpověd’mi hráčů v dotaznících. Zajímalo nás, který způsob hraní je motivoval více, zda ten na podložkách nebo ten na křížích, a jaká byla prŕčina jejich větší motivace.

\section{VÝSLEDKY}

Tabulka 1 Výsledky statistické analýzy neměrených hodnot TF

\begin{tabular}{|c|c|c|c|c|c|c|c|c|c|}
\hline \multicolumn{4}{|c|}{ Měření na podložkách } & \multirow{2}{*}{$\begin{array}{l}\text { úroveň } \\
\text { obtížnosti }\end{array}$} & \multicolumn{4}{|c|}{ Měření na křižíích } & \multirow{2}{*}{$\frac{\text { podložky / kříže }}{\mathrm{p}_{a, \mathrm{~b}}}$} \\
\hline PPR & $\mathrm{p}_{\mathrm{a}, \mathrm{b}}$ & $\bar{x}$ & $S_{x}$ & & $\bar{x}$ & $S_{x}$ & $\mathrm{p}_{\mathrm{a}, \mathrm{b}}$ & PPR & \\
\hline 1 a 2 & $\mathrm{p}_{1,2}<0,001$ & 114 & 21,6 & 1. & 107 & 24,5 & $\mathrm{p}_{1,2}<0,001$ & 1 a 2 & $0,05>p_{1,2}>0,01$ \\
\hline 2 a 3 & $\mathrm{p}_{2,3}<0,001$ & 133 & 29,2 & 2. & 121 & 26,0 & 0,06 & 2 a 3 & $0,05>p_{2,3}>0,01$ \\
\hline 1 a 3 & $\mathrm{p}_{1,3}<0,001$ & 141 & 27,6 & 3. & 123 & 25,7 & $\mathrm{p}_{1,3}<0,001$ & 1 a 3 & $0,01>p_{1,3}>0,001$ \\
\hline
\end{tabular}

Vysvětlivky:

$\overline{\mathrm{x}}$....... průměrná hodnota tepové frekvence (tepů / min.) pro danou úroveň obtížnosti

$\mathrm{s}_{\mathrm{x}} \ldots \ldots$ směrodatná odchylka tepové frekvence (tepů/min) pro danou úroveň obtížnosti

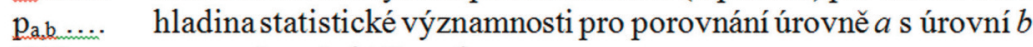

PPR... porovnávané obtížnosti

Porovnáním výsledků měření u rozdílných obtížností je pozorovatelný nárůst průměrné TF u podložek i u křižů. Statistická analýza potvrdila, že u cvičících na podložkách se průměrná TF statisticky významně zvyšuje v případě všech obtížností. U cvičících na křížích se TF zvýšila statisticky významně mezi první a druhou a první a třetí obtížností. Zvýšení mezi druhou a třetí obtížností je neprůkazné.

Při porovnávání výsledků měření dosažených při stejných obtížnostech jednak na podložkách, jednak na křížích, se potvrdila statistická významnost u všech tří obtížností. Analýza prokázala, že velikost TF na tanečních podložkách je vyšší než na kř́žźích. Intenzita zátěže při hraní PlayDance na podložkách je tedy vyšší.

Hráči hodnotili svou motivaci $\mathrm{k}$ pohybové aktivitě v rámci dotazníků. V sedmi př́padech hodnotili motivaci k pohybu na podložkách vyšší než na křížích. Nejčastějšími motivy byly: zpětná vazba/skóre (šest hráčů) a kontrola správnosti pohybu (jeden hráč). Jeden hráč vnímal vyšší motivaci na křížích. Jako důvod uvedl větší svobodu pohybu. U dvou hráčů nebylo možno rozlišit preference. U hraní na tanečních podložkách byla tedy motivace vyšší.

Výsledky prokázaly nárůst intenzity zatížení při zvyšování úrovně obtížnosti. Výjimkou je zvýšení obtížnosti 2 na obtížnost 3 u křížủ. Výsledky dále prokázaly vyšší míru intenzity zatížení při pohybu na podložkách. Dotazníkové šetření prokázalo vyšší úroveň motivace při cvičení na podložkách.

\section{DISKUSE}

Ve výzkumu jsme měřili rozdíly mezi intenzitou zatížení při hraní pohybové hry PlayDance na interaktivních podložkách, které hráčům poskytují zpětnou vazbu, a na křižích vyznačených na podlaze, které zpětnou vazbu neposkytují. Předpokládali jsme, že intenzita pohybové aktivity na podložkách bude vyšší než na křřžích. Analýza výsledků náš předpoklad prokázala ve všech třech obtížnostech jako statisticky významný. To znamená, že na podložkách byla intenzita zátěže aktivního hraní prokazatelně vyšší než na křížích.

Dále jsme porovnávali intenzitu zatížení u jednotlivých obtížností. Předpokládali jsme nárůst intenzity zatížení s rostoucí obtížností cvičení jak na podložkách, tak na kř́žích. Tento předpoklad se potvrdil u hraní na podložkách, nebot’ rozdíly mezi jednotlivými obtížnostmi a jejich dopad na nárůst intenzity zátěže byly během 
měření statisticky významně prokázány. Ovšem u hráčů na křižích se statisticky významně zvýšila intenzita zátěže pouze u přechodu z první na druhou obtížnost. U přechodu z druhé na třetí úroveň obtížnosti nelze u křížů potvrdit statistickou významnost předpokladu. Dle zdrojů závisí dosažení požadované intenzity zatížení na zvoleném stupni obtížnosti hráčem, který tak může reflektovat své momentální schopnosti. (Biddiss \& Irwin, 2010) Tato skutečnost implikuje opět otázku motivačních faktorů, nebot' na podložkách i kř́žích byly veškeré podmínky vyjma možnosti zpětné vazby shodné, a přesto byl prokázán nárůst intenzity zatížení z 2. na 3. stupeň obtížnosti pouze u podložek. Z toho vyplývá, že nárůst intenzity zatížení závisí také na úrovni motivace k aktivnímu hraní.

Příčinou výše zmíněných jevů je tedy pravděpodobně míra motivace $\mathrm{k}$ pohybu, kterou dle našeho dotazníkového šetření ovlivňuje zejména zpětná vazba, již měli k dispozici pouze hráči na podložkách, nikoliv na křížích. Prakticky dochází k tomu, že při hraní na podložkách se na displeji monitoru zobrazuje pořadí úspěšnosti jednotlivých hráčů, chybné kroky, a po každé skladbě se zobrazí čísla podložek tř́ nejlepších hráčů, zatímco hráčům na křižích žádné podobné informace poskytnuty nejsou. Vyhodnocením výsledků jsme dospěli k závěru, že zpětná vazba informující o úspěšnosti hráčů při hraní na podložce byla klíčovým motivačním faktorem k udržení intenzity zatížení. S ohledem na tvrzení, že úspěch plodí úspěch a účinky úspěchu a uznání jsou velmi silné (Petty, 1997), lze předpokládat, že absence zpětné vazby, a tudíž možnost soutěžit a být úspěšný způsobuje rozdíl v intenzitě zatížení př́i pohybové aktivitě na kř́žích oproti pohybu na podložkách.

Sledujeme-li výzkumy týkající se vhodnosti AVG jako zdravotně pozitivní pohybové aktivity, shledáváme, že úroveň intenzity zatížení je při AVG nižší než u procházky, avšak míra zábavy je rozeznávána zřetelně vyšší (Sell, Lillie \& Taylor, 2010). Mimoto má AVG velmi dobrý potenciál pro zlepšení aerobní výkonnosti (Peng, Jih-Hsuan, \& Crouse, 2011) a navíc, pokud je tímto druhem pohybové aktivity nahrazen sedavý způsob života, dochází k pozitivnímu ovlivnění životního stylu, a to i v př́padě, je-li hrána AVG s nižší než mírnou intenzitou zatížení. (Biddiss \& Irwin, 2010). Při celotělovém aktivním videohraní by však mělo dojít k dosažení střední intenzity zatížení. Průměrně 78\% věkem predikovaného maxima TF (Luke, Coles, Anderson \& Gilbert, 2005). Hraní AVG na křížích však nebylo dosud nikde statisticky měřeno.

Na základě výše zmíněných skutečností s AVG a svých výsledků shledáváme, že nelze doporučit alternativu hraní hry pouze na vyznačených křížích, jako samostatné a zdravotně efektivní pohybové aktivity, nebot' se zdá, že zde chybí motivace k udržení intenzity zátěže. Můžeme však doporučit skupinovou hru s využitím vyznačených kř́žů v kombinaci s podložkami za předpokladu, že se hráči na kř́ižích a podložkách pravidelně stř́dají, aby byla udržena jejich motivace.

Souvislost mezi intenzitou zatížení a motivací, spojenou s lepší zpětnou vazbou poskytovanou tanečními podložkami, by si zasloužila jistě hlubší zkoumání. Pro využitelnost hry PlayDance, např. ve školní tělesné výchově, je z ekonomických důvodů jistě nezbytné zkoumat možnosti udržení motivace také na kř́žích, např. zajištěním zpětné vazby pomocí zrcadel na stěnách sálu.

\section{ZÁVĚRY}

Výzkum potvrdil předpoklad, že míra intenzity zátěže při pohybu mimo podložku, tedy na vyznačených křížích, je nižší. Dále potvrdil, že většina hráčů preferovala jako zábavnější a více motivující pohyb na podložce oproti pohybu na křížích. Při sledování intenzity zátěže s rostoucí obtížností byly naměřeny výsledky, které potvrzují růst intenzity spolu s růstem obtížnosti, avšak tento předpoklad se nepotvrdil statisticky významně při přechodu z obtížnosti 2 na obtížnost 3 u kř́žzoù.

Nedoporučujeme proto používat při skupinovém hraní PlayDance výhradně vyznačených křižůu, nebot' naráží na problém udržení motivace hráčů. Lze však doporučit kombinace křížů s tanečními podložkami za předpokladu střídání hráčů na obou površích.

\section{Literatura}

Barnett, A., Cerin, E. \& Baranowski, T. (2011). Active Video Games for Youth: A Systematic Review. Journal of Physical Activity and Health. 8, 724-737.

Biddiss, E. \& Irwin, J. B. (2010). Active Video Games to Promote Physical Activity in Children and Youth. American Medical Association, 164 (7), 664-672. Retrieved 7. 3. 2012 from the World Wide Web: www: www.archmediatrics.com 
Dunning, T. (2008). Dance, Dance Revolution (DDR). Activities, Adaptation \& Aging, 32(3-4), 238-239. Retrieved 7. 3. 2012 from Taylor \& Francis online on the World Wide Web: http://www.tandfonline.com/ Gajda, V. \& Zvolská, J. (1982). Úvod do základních statistických metod pro posluchače tělesné výchovy. Ostrava: Pedagogická fakulta v Ostravě.

Kalman, M.; Hamř́k, Z.; Pavelka, J. (2009). Podpora pohybové aktivity pro odbornou veřejnost. Olomouc: ORE-institut.

Kalman, M., Sigmund, E., Sigmundová, D., Hamř́k, Z., Beneš, L., Benešová, D. \& Csémy, L. (2011). Národní zpráva o zdraví a životním stylu dětí a školákủ. Olomouc: UP v Olomouci.

Luke, R. C.; Coles, M. G.; Anderson, T. A.; Gilbert, J. N. Oxygen Cost and Hearth Rate Response During Interactive Whole Body Video Gaming [abstract]. Medicine \& Science in Sport \& Exercise, 2005, 37(5), S329. Retrieved 7. 3. 2012 from OvidSP on the World Wide Web: http:/ovidsp.tx.ovid.com/

Mohsen, B. (2005). Dance, Dance Revolution: The Next Big Technology device. Teaching Elementary Physical Education, 16(2), 36-39. Retrieved 3. 2. 2012 from EBSCO database on The World Wide Web: www.ebscohost.com

Peng, W., Jih-Hsuan, L. \& Crouse, J. (2011). Is playing Exergames Really Exercising? A Meta analysis of Energy Expenditure in Active Video Games. Cyberpsychology, Behavior and Social Networking, 2011, 14(11), 681-688.

Petty, G. (1996). Moderní vyučování. Praha: Portál.

Sell, K., Lillie, T. \& Taylor, J. (2010) Energy Expenditure During Physically Interactive Video Game Playing in Male College Students With Different Playing Experience. Journal of American College Health, 56(5), 505-511

Sigmundová, D., Ansari, E. A., Sigmund, E, \& Frömel, K. (2011). Secular trends: A Ten-year comparison of the amount and type of physical activity and inactivity of random samples of adolescents in the Czech republic. BMC Public Health, 11(731), 1-12.

Stejskal, P. (2004) Proč a jak se zdravě hýbat. Břeclav: Presstempus.

World Health organization (2010). Global Recommendations on Physical Activity for Health. Geneva: WHO Press. Retrieved 10. 2. 2012 from the World Wide Web:

http://www.who.int/dietphysicalactivity/factsheet_recommendations/en/. 